\title{
Tawwabin Uprising: The Emergence, Development and Influence on the Arab World
}

\author{
Ahmad Lamei Giv1,* \\ Leyla Falsafi ${ }^{2}$ \\ ${ }^{1 *}$ Faculty of Literature and Humanities, Department of Persian language and Literature, University of Birjand, Birjand, Iran \\ Corresponding Author: Ahmad.lamei2@birjand.ac.ir \\ ${ }^{2}$ Faculty of Literature and Humanities, Department of Islamic Education, University of Birjand, Birjand, Iran
}

\section{Doi:10.5901/mjss.2016.v7n3s1p439}

\section{Abstract}

Ashura uprising is an unparalleled scene in history as it portrays a peak in the history of oppression. Ashura reflects the betrayal and the failure of a number of elites who could cut ruthless hands of the government and prevent Ahlul Bayt to be persecuted with timely and appropriate use of opportunities. Quick result Imam Hussein's uprising in the political arena was uprisings, popular movements and several revolts in Muslim cities, which completely transformed the caliphate system. Tawwabin movement that the uprising was modeled after Karbala was carried out to avenge the blood of Imam Hussein (AS) for freedom of guilty conscience. Although it resulted in failure in terms of military dimensions, it had considerable consequences on the Muslim community and represents holiness, purity and depth of the beliefs that motivate it. Titled as "Tawwabin Uprising: The Emergence, Development and Influence on the Arab World," this research will find what are the reasons for calling the uprising as Tawwabin? Did it result in important achievement? Using a descriptive and analytical approach, it tries to describe factors and roots of its emergence, objectives of the movement and the impact it had on the Muslim community despite the failure of the uprising.

Keywords: Imam Hussein, Ashura, Tawwabin movement, goals, influences.

\section{Introduction}

As a reformer, Imam Hussein in Muslim nation could create epic and ardor, zeal and courage, and chivalry in Muslim nation as well as he brought to a boil the blood in the body of the Islamic nation with his testimony, which has been effective to revive Islam. He managed to bring the message of Islam in the best way with certain propagation methods in during fight and uprising. After his martyrdom, the convoy of prisoners, Ali Bin Al-Hussein (AS) and Hazrat Zeinab (SA) were the best missionaries of his message in informing society. Many people found that the essence of the caliphates were against Islam both in terms of shape and foundation and in terms of governance, law enforcement and the judiciary. Tawwabin uprising has been one of the most important results of this Shiite political movement.

\subsection{Research Objectives}

This article aims to investigate Tawwabin uprising, explore impact of the rise in the awakening of that time, and reply to doubt about the rise.

\subsection{Research Importance}

Constructive or destructive role of the Elites in various streams is not a secret. The right decision at the appropriate time by these people has a significant impact on the atmosphere of the Muslim community. Tawwabin movement analysis reveals the Elites' important role in society and in particular their role in the support and obedience to the ruler of the Islamic community. The importance of studying Tawwabin movement is understood from the speech of Ayatollah Khamenei in this regard; he states, "When Imam Hussein was killed, when the son of the prophet was lost, when the tragedy happened, when the movement began on the downhill side, what it matters? Although the number of Tawwabin was several times more than the number or the martyrs of Karbala in one day, the impact of Tawwabin on history was not at least one-thousandth of the martyrs of Karbala! Because they did not come in proper time, do not do at the moment, later decided and recognized" (Muhammadi Mutakazini, 2013: 31). As small and faithful companions of Imam Hussein 
(AS) on Ashura could delay his martyrdom with their presence, the presence of Tawwabin could change the outcome of the war in the day of Ashura.

\subsection{Research Questions}

Many articles have been written in the field with an emphasis on historical aspects; therefore, with emphasis on analysis of factors affecting Tawwabin movement, one can answer the following questions:

1. What is the reason for naming this movement as Tawwabin?

2. What are the major achievements of this movement?

3. Is is correct to argue that some Shiites who had invited Imam Hussein (AS) killed him in Karbala, or is it a biased suspicion?

\subsection{Research Hypothesis}

The hypotheses of this study include:

1. Tawwabin title is taken from the Arabic word "Tawubah" and refers to deep remorse of the elites and Shiites, followed by an attempt to compensate for thier failure.

2. Despite the strong motivation and conviction of its supporters, Tawwabin movement resulted in failure; but its impact on the Muslim community has compensated for the bitterness of defeat.

3. Although some articles and books have argued that the Shiites invited Imam Hussein (AS) fought against Ahlul Bayt, the researcher in this article believes that these people did not fight against Imam Hussein in Ashura despite the the Elites' negligence in the community in helping their Imam at the right time.

It should be noted that this research has been conducted through decriptive-analytical methods with emphasis on library-based methods.

\section{Literature Review}

Many useful works have been published about Tawwabin. Tawwabin Uprising by Muhammad Ali Chenarani and Tawwabin Uprising by Seyed Ali Muhammadi Mutakazini are the most notable ones. With respect to the historical review of the issue, this study is similar to the books; the difference is that the general issues discussed and the details have been passed. Each book has analyzed the history of Tawwabin from one point of view; this article tries to make a conclusion from the results of these two authors. This is a different research due to its analytical aspects and the answers to raised question. It is worth mentioning that the author has attempted to avoid any analysis leading to misunderstanding. Since various articles have been written on this subject and most of them have historical-narrative method, this article refers to the most original works and avoids using these articles.

\subsection{Semantic Range of the Word Tawwabin}

The term Tawwabin means regretted persons. Tawwba means return from sin and repentance of sin (Tarihi, 1983, vol.1: 300). Repentance has some elements including:

A) the person' knowledge and certainly that he has been disobedient in the past.

B) Regret from the actions ha has committed.

C) Decision to leave it in the future and compensate for past (Tafsir Nemuneh, 1984, vol. 2: 96).

\subsection{Tawwabin Appellation}

As noted above, repent has three pillars; historical evidence proves the existence of the pillars in the Tawwabin's thought and action:

A) After the martyrdom of Imam Hussein (AS) and his companions, all people who had failed said there is no way for them unless repent and return, except to be killed for the revenge of Imam Hussein (AS) ... then; they moved to Levant to avenge. Hence, they were called Tawwabin (Ibn Saad, 1418 Hiji, Vol. 4: 219).

B) After the martyrdom of Imam Hussein (AS), enmity and hatred of Muslims rose against the Umayyads and their governors so that the Shiite revolt in Kufa in 65 Hijri. They became regretful and repented from their work; therefore, they were called Tawwabin (Ibrahim Hasan, 2007, vol. 1, p. 401). 
C) After the martyrdom of Imam Hussein (AS) and death of Yazid, the Kufis came together. Since that had invited Imam Hussein and and promised any help to him (but they failed to fulfill their promise), they were regretted and repented; hence, they are called Tawwabin (Ibn Wadhih, n. d, Vol. 2: 257).

Thus, the root of this term backs to these people's guilty conscience and regret and their effort to compensate for their failure in helping their Imam.

\subsection{Socio-Political Situation of Islam World during Tawwabin Movement}

In less than half a century since the mission of the Prophet, world of Islam was subject to various events and the government fell into the hands of those who do not believe in Islam; Islam was merely a tool to legitimize their rule. Mecca was governed by Zubair. Medina was under the influence of Hore event, which occurred in 63 Hijri after a revolution against Yazid oppression system in order to react to the martyrdom of Imam Hussein (AS). The event occurred in a Sabulous near Medina where troops of Yazid were its inhabitants. In addition to affront to the city of the Prophet, Yazid allowed soldiers to exceed people and their properties for three days. Turbulent Kufa due to Karbala incident was still in amazement and disbelief. Imam Hussein uprising showed its most effect on Kufa. Yazid's death greatly weakened the rule of the Umayyads. Therefore, it leads to various uprising, movements and riots.

The picture imagined from the situation of Kufa during the Tawwabin uprising is described as: Yazid was killed and Iraqi people were not forced to endure him. Shiites showed their opposition clearly. The Iraqi people were not willing to accept Levant government. Therefore, coincide with the Shiites' invitations, not only the masses but also those who saw their position in danger or had been influenced by the spirit of the people, declared their support for Imam Hussein (Ahmad ibn Atham, 1406 Hijri, Vol. 5: 50)

Uprisings in the era of Shiite Imams can be divided into two categories, which Tawwabin movement is categorized in the second type:

1. Uprisings aimed at the return of the caliphate to Ahlul Bayt, which were approved by Ahlul Bayt.

2. Uprising to achieve personal goals, which werecondemned by Ahlul Bayt.

\subsection{Background of Tawwabin}

People who invited Imam Hussein were from three groups: the Hypocrites, the Survivors, the failures.

\subsubsection{The Hypocrites}

They represents their real personality in different situations and endanger the uprising badly. They sent letter to Imam when they saw that Yazid caliphate was going to be declined due to numerous letters to Imam; with the suppression of the Moslem movement, they changed their idea and showed their real personality. Even, they rallied against Imam in Ashura.

\subsubsection{The Survivors}

Individuals like Habib ibn Mazahir, Abdollah ibn Kalbi, Moslem ibn Osejeh who helped Imam Hussein and and eventually martyred.

\subsubsection{The Failures}

They were people who failed to help Imam due to different reasons. Some helped Imam later in Tawwabin uprising to compensate for their past deeds.

Some reasons for their failure to help Imam can be classified in the following groups:

\subsubsection{The imprisonment of many of them}

With an understanding of the Shias of Kufa, Ibn Ziyad imprisoned many Shiite heads and leaders, who had not joined Imam to prevent their help to Imam. 


\subsubsection{Prevention of notifications}

Imam was aware of the political-social situation in Kufa through couriers who were sent Kufa. With the martyrdom of Qeis ibn Mosher Seidawi, Imam's last courier, Imam's coonection to the Kufis was cut. Hence, the shias were unaware of Imam's situation.

\subsubsection{Weakness and negligence of some Shiites}

As Balazari writes, "Said ibn Obeideh said: some of our Sheikhs were standing on a hill and pray: Oh, God send your hrlp to Hussein." Said assert tha I asked them why don't you come down to help him? (Balazari, 2013, vol. 3: 225).

This is It is more likely about other Kufis; but it is less reasonable about leaders of Tawwabin movement who were oldest and most trusted companions of Imam Ali (AS) (Muhammadi Mutakazini, 2008).

\subsubsection{Pressure by ibn Ziyad}

According to historians, ibn Ziyad threatened people and appointed some spys to search and identify offenders (Balazari, 2013).

\subsubsection{Strict control of roads}

Strict control and closure of roads to Karbala were the most important reasons for failure of the Kufis to help Imam.

Some people left the cities to help Imam; thes, ibn Ziyad controled raods from Levant to Basra and prevented individuals to enter or exit (Balazari, 2013).

As it is mentioned before, some contradictions in the words of the biased person arguing the Shitte invitors of Imam Hussein were his killer in fight. Although some Kufi Shias failed to help Imam Hussein (AS) due to lack of sufficient insight and weaknesses belief in Imam, they had never fought against Imam. Therefore, it is clear that some individuals try to transgress Shia with intentionally or unintentionally wrong reasoning about the event. However, this argument will never justify the failure of companions and the Shias in helping Imam Hussein (AS).

Undoubtedly, bloody uprising in Karbala and missionary movement Ahl al-Bayt (AS) has blown the spirit of awareness and anti-tyranny in the dead body Islamic society and awakened a wide range of Islamic society. The tragic incident informed the Elites who had failed to fulfill their duties in Karbala.

\section{Awakening of the Shiite Community Kufa}

Ashura causes Kufis' awakening from their slumber and crystallization of guilt sense among the Shia. This awakening can be due to some of the following factors:

\subsubsection{Past regret and compensation}

Missionary movement led by Imam Sajjad (AS) and Hazrat Zeinab (SA) after rending event of Karbala awakened the hearts of dormant ignorant Muslim community as a massive storm. Without a doubt, negligence in helping Imam Hussein in Karbala by the Shiites of Kufa was led to regret in the Elites of Kufa. Therefore, they sought to repent, to appease the family of the Prophet (S), and revenge on the oppressors. It should be noted that history has shown repentance and revenge could never compensate for the missing in the convoy of Karbala.

\subsubsection{Enlightenments by Ahlul Bayt (AS) and awakening of Tawwabin}

Insightful and thoughtful approach of Imam Sajjad (AS), Hazrat Zeinab (SA) and others not only provoked Kufis and Damascene but also uncovered the real face of Ale Umayyad. Rousing sermons and elegy of Ahlul Bayt (AS) dropped a flood of tears from the Kufis' eyes while they regretted. Under the influence of the powerful words of Ahlul Bayt (AS), Although Damascene had grown up in the governance of Muawiyah and did not understand the real Islam, they protested to Yazid so that Yazid was forced to claim that the responsibility for the killing of Imam Hussein (AS) is to Obaidollah ibn Ziad (Jazari, 2014). Ahlul Bayt (AS) was sent to Medina with the idea that if they returned to the city of Medina, their file would be closed in Karbala forever. This led to people's brace, the start of Medina uprising, and Hareh event, which were a stigma for Yazid and the Umayyad. 


\subsubsection{Leadership}

The leaders of a movement play significant roles in the movements and their aims. Leadership, its strengths, and its weaknesses have essential roles in success or failure of the movement. Researchers and analysts always explicitly point out the prominent role of leadership and its remarkable impact on the advancement of the revolution. In addition to the positive impact on people, shocking and exciting remarks Tawwabin's leaders delivered at a formal meeting caused the absorption of the forces failed to help Imam Hussein (AS) (Tabari, 1983).

\subsubsection{Revenge}

Since Islam is opposed to any oppression against an individual or a society, it considers confrontation with the oppressors to save the rights of the oppressed as a praiseworthy and sometimes necessary. Al Umayyads' oppression on the family of the Prophet (PBUH) and the captives in Karbala strengthened the Tawwabins' motivation to avenge the blood of Martyrs (AS). When the epic slogan "Ya Hussein Lsarat" resonated in Kufa, it was like an earthquake on the aristocracy and the killers of Imam Hussein (AS). The group took their weapons, formed the enormous power beside the holy shrine of Imam Hussein (AS), and made a covenant with him (Tabari, 1983). Sense of revenge is an important factor in motivating the Kufis and accompaniment with the Shiite movement. These factors were effective in the awakening of Kufis Shiites; hence, society became ready for Tawwabin uprising.

\section{Factors Influencing the Formation of the Tawwabin Uprising}

Like any movement, Tawwabin uprising has a context that paving the way for the uprising. Tawwabin began in 61 Hijri after the martyrdom of Imam Hussein (AS); but it was not public until 65 as they invited people to collect weapons.

\subsection{The first meeting of Tawwabin}

In 50 Hijri, they held a meeting at Sulayman ibn Surad Khazaei's house after hearing the news of the martyrdom of Imam Hassan (AS). They wrote a letter for condolences testimony of his brother to Imam Hussein (AS) (ibid. Vol. 2: 228). In 60 after the death of Muawiyah, they sent him letters themed invitations to go to Kufa. (Ibid., Vol. 5, pp. 352-353). The Tawwabins' next meeting after the martyrdom of Imam Hussein (AS).

\subsection{The Tawwabins' invitation from other Shiite cities}

In the first meeting, Sulayman ibn Surad Khazaei was selected as the General Commander of Tawwabin forces. At the end of the meeting, he wrote letters to Shiite elders and leaders in various cities to join for avenging the killing of Imam Hussein (AS) (Chenarani, 2004).

\subsection{Yazid's death}

Imam Hussein (AS) was martyred in 61 Hijri. Tawwabin began its hidden activities in this year and ontinually work to provide the tools of war and prepare for war. People began to join them until the year Yazid ibn Muawiyah died in 65. After the death of Yazid, people showed their allegiance with Sulayman easier (Chenarani, 2004).

\subsection{The new governor of Kufa and Tawwabin}

After the death of Yazid, his governor in Kufa (Amr ibn Harith) was driven outside palace by people; then, people were allegiance to Abdullah bin Zubair. Abdullah bin Zubair appointed Abdullah bin Yazid the governor of Kufa and he announced his support for Tawwabin uprising (Chenarani, 2004). In this way, Tawwabin activities were pursued seriously with sacred goals and objectives.

\subsection{Objectives of Tawwabin uprising}

Every uprising or movement must have valid goals to attract public support. The goals of an uprising could determine to some extent the nature of the movement. The following are some of the objectives of Tawwabin uprising: 
1. Restoring the right of Ahlul Bayt (as). (Tabari, 1983)

2. Following Quran, the Sunnah or revenge for Ahlul Bayt (AS). (Tabari, 1983)

3. Revenge on the killers of Imam Hussein (AS). (Tabari, 1983)

4. Compensation of sins. (Tabari, 1983)

5. Establishing the truth and destroying falsehood. (Tabari, 1983)

\section{The Leaders of the Uprising}

Elders or leaders of the uprising can be divided into two groups:

\subsection{First grade leaders}

The main leaders of the movement were five including Sulayman ibn Surad Khazaei, Mosayeb ibn Najabeh, Abdullah ibn Saad ibn Nouyel, Abdullah ibn Wal Teimi, Refah ibn Shadad Bajali (Chenarani, 2004).

\subsection{Second grade leaders}

Except the five responsible men for the revolt, other well-known influential people involved in the uprising. They were Karib ibn Zayd Homeiri, Sakhir Mozani, Abdullah ibn Aziz, Abdullah ibn Khozal, Homaid ibn Moslem, Hansh ibn Rabie (Chenarani, 2004).

During the meetings, the leaders of the uprising decided to request help from other cities in Iraq or outside of Iraq.

\section{Strategic Cities in Tawwabin Movement}

In the story of the Tawwabin uprising, some cities were involved in helping them since the beginning to the end of the uprising. They were:

\subsection{Kufa}

This city was made in 17 Hijri by Sa'ad bin Abi Waqqas (Tabari, 1983). The city was the center of movement and of the uprising's heart was beating in the city.

\subsection{Basra}

As Iraq's second city, Basra was constructed in 14 Hijri by Umar (Mufid, 1988). Three hundred of these people came from Basra to help in Tawwabin uprising, but they were late and the Tawwabin had been defeated; thus, they returned without the involvement (Massoudi, 1404 Hiji; Vol. 3: 94).

\subsection{Madain}

Madain, whose Persian name is Ctesiphon, was conquered by Sa'ad bin Abi Waqqas by the order of Umar in 16 Hiji (Jazari, 2014). One hundred and seventy people from this city came to help Tawwabin; but they met the defeated and injured forces in Heit. They separated from each other and returned to their cities after a lot of crying; then, they joined Mukhtar uprising (Massoudi, 1404 Hijri, Vol. 3: 94).

\subsection{Circesium}

Circesium was an ancient city in Osrhoene, corresponding to the modern city of Buseira, in the region of Deir ez-Zor in Syria, at the confluence of the Khabur River with the Euphrates. It was a very prosperous city. In addition to military guidance, it ruler, Zufar ibn Harith al-Kalbi, helped Tawwabin financially and support them by war supplies, food and camels. Moreover, he lodged them at their return for three days, treated the wounded troops, and feed them for their return to their home (Massoudi, $1404 \mathrm{Hijri}$ ). 


\section{The Beginning of Tawwabin Movement}

After the meeting of its leaders, Tawwabin uprising began in 65 Hiji with indescribable enthusiasm to achieve its aims. In its first consultative meeting held in the house of Sulayman ibn Surad, after passionate speeches leaders of the uprising, the following results were obtained:

- Sulayman ibn Surad headed the movement

- Outlining the political and military lines

- Correspondence and sending a message to Iraq and Shiite areas outside Iraq

- Secrecy for movement development until proper time

- Collecting money and gifts from the Shiites to buy arms and military equipment

- Members' agreement on the time of uprising to began first of Rabi in 65 Hijri (Muhammadi Mutakazini, 2009: 89).

The decision for Tawwabin movement was in 61 Hijri, but it was started in 65 hijri. After several years of secret organizing, they moved to Nokhayleh to go to Levant with a population of 4,000 people by the motto "'Ya Hussein Lsarat"

\subsection{The path of Tawwabins movement}

As mentioned, Tawwabin equipped its army secretly nearly three years and moved from Kufa to Nokhayleh eventually in 65 Hiji. They were waiting three days to join other forces.

At the place of his followers' gathering in Nokhayleh, Soleiman states, "Nothing but Jihad and prayer can close you to God because Jihad is a sign of action." Beidhoon, 1979: 52).

As usual, the Kufis broke covenant and many of them did not attend in Nokhayleh despite their promise.

Abdullah ibn Yazid (Ibn al-Zubayr's representative) met them and tried to attract the Tawwabins; but he was unsuccessful and the army moved to Deire Aour immediately after the return of Abdullah ibn Yazid. The second stopover of Tawwabin was Deire Aour, which spent the night there. (Tabari, 1983, Vol. 4: 456). Then, they moved to Aqsas and stayed in a place called Aqsase Malik. The fourth stopover, which was the most spiritual one, was Karbala.

The army move at night from Aqsas and reached Karbala in the morning. They stayed there for a day and night (lbid: 456).

They said next to the tomb of Imam Hussein (AS), "Oh Lord, We refused to help the son of Your Prophet, forgive us have mercy upon us and redeem us" (Ibn Athir, 1991, vol. 6: 2370).

After Karbala, they departed to Anbar and Qyareh.

Abdullah ibn Yazid's next letter and his invitation indicating unity against the same enemy was reached to Sulayman. It was a futile attempt by the governor of Kufa; they arrived Heit. After passing through Aenat, they reached to Circesium. Zufar ibn al-Harith was ruling Circesium. At the request of Musayyib ibin Najabeh, he ordered to establish a market for the necessities of Tawwabin army. Zufar gave proper facilities and good food to the army and provided them military guidance had information for their journey. Finally, they stopped at Ein al-Wardeh and waited five days for the enemy.

In the first day of the war, Tawwabin defeated the Umayyads and killed most of them (Ibid. Vol. 7: 74). In the second day, the battle lasted until sunset without winning any of the parties (Jazari, 2014). In the third day of the battle, the Umayyads had mobilized, Tawwabin had lost many soldiers, and Tawwabin found themselves surrounded by the Umayyads; butthey fought bravely, heroic and with firm faith (Massoudi, 1404 Hijri, Vol. 3: 94). Tawwabin won the war in the first and second days of the war against with enthusiasm and a strong faith in a higher purpose; but it was a temporary victory and the table turned in third day in favor of a Damascene.

\subsection{End of the battle and returning to Kufa}

Tawwabin battle with Damascene lasted until the end of the third day and all leaders of Tawwabin except Rifa'a bin Shaddad were martyr. He gathered the survivors of Tawwabin and commanded return. On the way back, they met the Shiites of Madain and Basra who came to join Tawwabin. They returned to Circesium and departed to travel to their land after resting there (ibid).

Persistence and courage of Tawwabin helped them not to be massacred by the Levant army and they could withstand night to night" Razavi Ardekani: 35).

The next day, ibn Ziyad's corps commander found their escape; but refused to follow them (Tabari, 1983, Vol. 4: 
470). In Circesium, Zufar ibn Harith welcomed the Tawwabins and and they were offered condolences. Then, he treated the wounded men and they were sent to their countries (Balami, 1980: 56)

However, Tawwabin lost the war against the Damascenes and the wounded persons went to their homes with broken hearts. The Shiites in Madain and Basra joined Tawwabin tearful eyes.

Historical evidence suggests that Tawwabin helping forces had not deliberately delayed. The reasons for this statement can be:

1. Tawwabin rose before the due date; thus, the people of Basra and Madain were not yet ready (Leithi, 1984: 31).

2. People of Basra and Ctesiphon had not provided their required equipment and facilities. This fact can be understood from the words of Sulayman ibn Surad Khazaei (Tabari, 1983, Vol. 4: 455).

3. Participation of people from Basra and Medina indicates their failure; it reflects honesty and signifies the unity of the two cities (Chenarani, 2004: 134).

With all the effort and conviction in pursuit resurrection by Tawwabin, the bitter taste of defeat bitter Shiite community.

\subsection{Reasons for the failure of Tawwabin uprising}

Undoubtedly, the failure of Tawwabin in Ein al-Wardeh was due to military inequality. The Umayyads army was an army organized, experienced, and very rich in terms of military equipment. Nevertheless, Tawwabin army was weak in terms of military organization and military equipment, despite the firm conviction, strong will and great faith in the legitimacy of their uprising. It is clear that other factors had significant roles in the defeat of the uprising, indirectly; the following are mentioned:

- Reliance on unstable and coward people of Kufa

- Lack of specific social-political goals

- Neglecting capture and establishment of security in Kufa

- Concurrence of two parallel uprising (Tawwabin and Mukhtar) and efforts to recruit by leaders

- Lack of sufficient troops and equipment

- Lack of attention to the social implications of the revolution and lack of strategy in the Tawwabin uprising

- Hastiness in military confrontation

- Inaccuracy in secret strategies

- Lack of military intelligence

- Too much attention to the emotional aspects of the uprising (to kill or to be killed)

As mentioned, there are several effective reasons for the failure of the uprising; but the defeat cannot eliminate its important effects on the community.

\subsection{Tawwabin uprising influence on the Muslim community}

As each movement and uprising has goals and contexts, it has impact and reflection on society. Some of these include:

\subsubsection{Making the enemies of Ahlul Bayt (AS) worry}

When the motto of "Ya Hussein Lsarat" resonated, it was like an earthquake on the aristocracy and the killers of Imam Hussein (AS) so that Bagher Sharif Qoreishi said, "However, Tawwabin uprising made offenders, criminals, the killers of Imam Hussein (AS) full of fear, worriness' it prepared the Shia for fighting against the Umayyads (Sharif Qoreishi, 1993, vol. 2, 673).

\subsubsection{The awakening of Muslims}

The main goals of the uprising were awakening the conscience of Muslims, inciting them to revolution and protest against the rule of tyranny and corruption of the Umayyad, and motivate the Islamic spirit. First, Tawwabin movement had religious and promotional purposes; it was achieved at the end (Modaresi, 1998: 68). 


\subsubsection{Realization and manifestation of other uprisings}

Tawwabin uprising led to Mukhtar uprising and Mukhtar uprising led to Zeid ibn Ali's uprising; then Yahya, the son of Zeid, rose; finally the Umayyads declined due to such revolutions.

If Tawwabin had not risen, other uprisings would never be begun. Sulayman ibn Surad Khazaei's defeat in Ein alWardeh is regarded as a standpoint in the history of Shia development (Eftekharzadeh, 1998: 181).

Apart from the results, every uprising has some teaching for next generations. Some of the teachings of the movement will be discussed in the following.

\subsection{The teachings of Tawwabin uprising}

Insightful people are always seeking to find and and evaluate the facts and various aspects of their uprisings. Some teachings of this uprising are:

1. The need for decisions at the right time by the Elites.

2. The need to deal with threats at the right time.

3. The need for appropriate organization to deal with the enemy.

4. Optimum use of the opportunities.

5. Following the reason and avoiding sensations (Mohammadi Mutekizini, 2008: pp. 121-127)

Ashura was the school of love and a symbol of battle of truth against falsehood. It was a divine revolution realized more with the passage of time; and its teachings uncovered later. The more a person is familiar with hidden teachings of the movement, the more will be his self-esteem; in this regard, he can undermine the foundations of the tyrants' rule. Karbala acquainted human beings with the noble values and high and meaningful concept of life. As the first wave of Ashura, Tawwabin uprising had a fatal blow on the body of the Umayyad governance.

\section{Conclusions}

Studying Shiite uprisings is a considerable and important issue in the history of Islam because these uprisings and movements have had significant impacts on human life throughout history. This research indicates that Tawwabin uprising was an uprising based on feelings and hasty. They rose to revenge on the blood of Imam Hussein (AS) for freedom of their own conscience. They believed that they must stand on their belief to their death to compensate for the delays to help Imam Hussein (AS). The uprising was modeled after the movement in Karbala. In other words, despite their belief in defeat, they welcomed death with indescribable enthusiasm.

In addition, enlightened efforts by Imam Sajjad (AS) and Hazrat Zeinab (SA) after the incident of Karbala was effective in its realization. With respect to reasons such as the imprisonment of a number of prominent followers, pressures by ibn Ziyad, strict control of paths, and cutting informing Kufa, it is reasonable to argue that Kufis did to attend in war against Imam Hussain (AS) although some of the Shias of Kufa were unsuccessful to help Imam Hussain (AS) due to their lack of sufficient insight.

They were also weak in terms of military tactics and techniques because they thought that the important issue is their sacred purpose either they would be winner or loser. It should be noted that the Tawwabins' military defeat was not meant their political defeat as they achieved their ideals and had positive influences on other Shiite movements. Tawwabin movement is important because it had no conciliatory positions and aiming to take revenge on the enemies and murderers of Imam Hussein (AS).

Tawwabin uprising had many achievements for the Muslim community including the awakening of Muslims, fear in the hearts of the enemies of Islam, and realization of uprisings such as the uprising by Mukhtar.

With respect to the importance of the subject in current ages, researchers can focus on this group and investigate the participation of Tawwabin in different periods and their role in crucial moments in the history to uncover the effects of the Elites in Muslim community for the future.

\section{References}

Balami, Abolfazl (1980). Imam Hussein uprising and Mukhtar vengeance. Ed. Muhammad Sarvar Molaei, Tehran: Iranian Cultural Foundation.

Balazari, Ahmad ibn Yahya (2013). Genealogies of the Nobles: A research by Bagher Mahmoodi, Beirut: A'lami Publication, vol. 3.

Beidhoon, Ibrahim (1979). Tawwabin Uprising (Soleiman Ibn Sorad Khazaei). Translated by Karim Zamani, Tehran: Foroughe Danesh 
and Hekmat Publication.

Chenarani, Muhammad Ali (2004). Tawwabin uprising. Mashhad: Astan Quds Razavi.

Eftekharzadeh, Mahmood Reza (1998). The political history of early Islam, narrated by Salim bin Qais, Tehran: The mission of the pen. Hasan ,Ibrahim Hasan (2007). The political history of Islam. Trans. Abolqasim Payandeh, Tehran: The World of Knowledge, Volume 1. Ibn Atham, Ahmad (1406 Hiji). Al-Futuh, Beirut: Daralketab Ellmiyeh, Volume 5.

Ibn Saad Ahmad (1418 Hijir). A-Tabaqatul Al-Kubra: A research by Muhammad Abdulqadir Ata. Beirut: Daralketab Ellmiyeh, Volume 4. Ibn Wadhih, Ahmad (n.d). Tarikh al-Yaqubi. Beirut: Daralsadir, Volume 2.

Jazari, Ibn Athir (2014) Al-Kamil fi al-Tarikh. Beirut: Daralketabs Arabi, Volume 2, 4.

Ibn Athir, (1991). The Compelete History. Translated by Muhammad Hussein Rohani, Tehran: Asatir, Vol. 6.

Leithi, Samireh Mukhtar (1984). Hihad al-Shia, N.P.: Batha.

Makarem Shirazi et al (1983). Nemuneh Tafsir. Vol. 2, Tehran: Islamiya.

Massoudi, Ali Bin Al Hussein (1404 Hijir). Meadows of Gold and Mines of Gems. Vol. 3.

Modaresi, uhammad Taqi (1988). Shiite imams and ideological movements. Translated by Yaqoub Azhir, Mashhad: Islamic Research Foundation.

Mufid, Muhammad ibn Muhammad (1988). Jamal battle. Translated by Mahmood Afghani, Tehran: Nei Publications.

Muhammadi Mutakazini (2008). Tawwabin uprising. Qom: IRIB Islamic Research Center.

Muhammadi Mutakazini, (2013). Those who remained, Tehran: Ketab Shahr.

Razavi Ardekani, Abu Fazel (n.d.). The Consequences of Ashura, Research Institute for Publication of Ahlul Bayt's Teachings.

Sharif Qoreishi, Bagher (1993). Analysis of the life of Imam Sajjad (AS), translated by Mohammad Rezaei, Mashhad: Congress of Imam Reza (AS), Volume 2.

Tabari, Muhammad ibn Jarir (1983). Tabari History. Translation Abolghasem Payandeh, Tehran: Asatir.

Tarihi, Fakhreddin (1983). Majmaol Bahrain. Tehran: Tarawat. 